\title{
Avaliação do potencial da macaúba para produção de biodiesel e seus impactos sociais.
}

\author{
João Pedro de Oliveira Baptistini Lopes*, José Maria Ferreira Jardim da Silveira.
}

\begin{abstract}
Resumo
A pesquisa tem como objetivo realizar um mapeamento das regiões com potencial para a produção de macaúba no território brasileiro, identificando os principais sistemas produtivos e suas potencialidades para produção familiar. Foi analisada também a estrutura da matriz energética mundial, assim como o futuro previsto para ela. Realizou-se uma comparação com outras matérias primas utilizadas na produção de biodiesel, identificando os pontos críticos e potenciais usos para o óleo da macaúba.
\end{abstract}

\section{Palavras-chave: \\ Macaúba, Biodiesel, Potencial}

\section{Introdução}

Diante de uma matriz energética mundial, caracterizada pela intensa dependência de fontes de energia não renováveis, as últimas décadas do século $\mathrm{XX}$ foram marcadas pela ampliação dos questionamentos desse modelo. Em um primeiro momento, alguns produtos que anteriormente eram pouco valorizados, como o gás natural, ganharam mais força e abriram caminho para substitutos do combustível fóssil, como o biodiesel.

A partir da crescente demanda por biocombustíveis e, consequentemente, suas matérias-primas, a macaúba, uma possível alternativa às tradicionais fontes de biodiesel, passa a ganhar maior atenção pelos diversos modos como pode ser aproveitada, ampla dispersão no território brasileiro e resistência às adversidades.

O objetivo deste projeto é realizar um mapeamento das regiões com potencial para produção de macaúba no Brasil, identificando os possíveis usos para o seu óleo, os principais sistemas produtivos, e suas potencialidades para produção familiar. O presente trabalho também tem como foco realizar uma análise comparativa com outras matérias primas para a produção de biodiesel, identificando os pontos críticos e favoráveis ao uso do óleo da macaúba.

\section{Resultados e Discussão}

A macaúba é uma palmeira nativa das florestas tropicais e sua distribuição geográfica é bem ampla. No Brasil, sua presença se dá em quase todo o território. Apesar da existência de povoamentos naturais em diversas regiões, as maiores concentrações ocorrem no cerrado e no pantanal, sobretudo em Goiás, Mato Grosso, Mato Grosso do Sul e Minas Gerais.

Naturalmente, a produção com objetivo comercial tem mais chances de ocorrer em regiões com maior concentração de macaúba. Uma grande vantagem da cultura da macaúba com a finalidade de produção do óleo é que ela pode ser integrada em vastas pastagens existentes sem prejudicar os rendimentos pastoris, podendo inclusive ser utilizada para produção de forragem para animais. A macaúba também pode ser plantada em sistemas de cultivo solteiro ou consorciado. Contudo, a princípio, a exploração destes dois últimos sistemas ainda não é tão promissora quanto a do sistema silvipastoril.

A macaúba foi identificada como a espécie nativa mais promissora para a produção de óleo vegetal e biomassa, tendo grande potencial de uso, desde o caule até a semente. $\mathrm{O}$ fruto representa a parte cultural e econômica mais importante da planta, podendo ser consumido in natura ou utilizado para produção de óleo. Este óleo tem inúmeras aplicações, podendo ser utilizado na produção de alimentos, produtos farmacêuticos, cosméticos e biocombustíveis.

Esta palmeira pode produzir até 10 vezes mais óleo por área do que a soja, além do amplo aproveitamento de coprodutos (ROSCOE, RICHETTI \& MARANHO, 2007). De acordo com estimativas, essa oleaginosa pode produzir 4500 litros de óleo por ha/ano, quantidade bastante superior a outras oleaginosas com produção anual, como o girassol e a mamona.

Apesar do potencial de uso, a exploração da espécie é efetuada de forma extrativista e seu beneficiamento quase sempre artesanal.

\section{Conclusões}

Dentre as alternativas para produção de óleo para consumo humano, indústria óleo-química e biocombustíveis, a macaúba tem um grande potencial. Apesar do aproveitamento por parte de algumas comunidades próximas às populações naturais, a exploração do potencial da macaúba é algo incipiente e pouco relevante em termos de acréscimo a diferentes cadeias produtivas do mercado de óleo e coprodutos.

O cultivo de macaúba com objetivo comercial é algo que ainda precisa ser estruturado. Como os produtores tendem a buscar por algo mais confiável, rápido retorno e menores riscos, o plantio em sistemas de cultivo solteiro pode sofrer uma maior resistência.

Contudo, a produção da macaúba em sistemas silvipastoris é vista como algo promissor. A integração da palmeira às pastagens existentes poderia gerar renda adicional sem prejudicar os rendimentos pastoris. Além disso, também proporcionaria um impacto positivo na questão sustentável, aumentando a biodiversidade e diminuindo a degradação ambiental.

MÖSSINGER, J.; SIEBOLD, M.; BERGER, T. Neglected Crops as a Diversification Strategy - An Economic Assessment for Paraguayan Smallholder Systems in Times of Bioeconomy. 2015.

ROSCOE, R., RICHETTI, A. \& MARANHO, E. Análise de viabilidade técnica de oleaginosas para produção de biodiesel em Mato Grosso do Sul. Revista Política Agrícola. 2007

VILELA, M. F. et al. MACICOS NATURAIS DE MACAÚBA (Acrocomia aculeata): MAPEAMENTO E ANÁLISE DO POTENCIAL PARA PRODUÇÃO DE BIODIESEL. Planaltina-DF: Embrapa, 2014. 